\title{
Extreme postcranial pneumaticity in sauropod dinosaurs from South America
}

\author{
Ignacio A. Cerda $\cdot$ Leonardo Salgado • \\ Jaime E. Powell
}

Received: 18 November 2011/ Accepted: 21 May 2012/Published online: 5 June 2012

(C) Springer-Verlag 2012

\begin{abstract}
Birds are unique among living tetrapods in possessing pneumaticity of the postcranial skeleton, with invasion of bone by the lung and air-sac system. Postcranial skeletal pneumaticity (PSP) has been reported in numerous extinct archosaurs including pterosaurs and nonavian dinosaurs. Here we report a case of extreme PSP in a group of small-bodied, armored sauropod dinosaurs from the Upper Cretaceous of South America. Based on osteological data, we report an extensive invasion of pneumatic diverticula along the vertebral column, reaching the distal portion of the tail. Also, we provide evidence of pneumaticity in both pectoral and pelvic girdles. Our study reveals that the extreme PSP in archosaurs is not restricted to pterosaurs and theropod dinosaurs.
\end{abstract}

Keywords Sauropoda - Titanosauria - Upper Cretaceous . Air-sac system · Appendicular pneumaticity

I. A. Cerda ( $\square)$

Consejo Nacional de Investigaciones Científicas y Tecnológicas (CONICET), Instituto de Investigación en Paleobiología y Geología, Universidad Nacional de Río Negro, Museo Carlos Ameghino, Belgrano 1700, Paraje Pichi Ruca (predio Marabunta) 8300, Cipolletti, Río Negro, Argentina

e-mail: nachocerda6@yahoo.com.ar

\section{Salgado}

Consejo Nacional de Investigaciones Científicas y Tecnológicas (CONICET), Instituto de Investigación en Paleobiología y Geología, Universidad Nacional de Río Negro, Isidro Lobos y Belgrano CP 8332, General Roca, Río Negro, Argentina

J. E. Powell

Consejo Nacional de Investigaciones Científicas y Tecnológicas (CONICET), Facultad de Ciencias Naturales, Universidad

Nacional de Tucumán, San Miguel de Tucumán, Argentina
Kurzfassung Vögel sind einzigartig innerhalb der lebenden Tetrapoden, da sie eine Pneumatisierung des Postkranialskeletts aufweisen, welche die Invasion von Knochen durch die Lunge und Luftsack-Systeme einschließt. Diese postkraniale Skelettpneumatisierung (PSP) ist bereits in zahlreichen ausgestorbenen Archosauriern, einschließlich Pterosauriern und Dinosauriern, die nicht der Vogellinie angehören, beschrieben worden. Hier berichten wir über einen Fall von extremer PSP in einer Gruppe von kleinwüchsigen, gepanzerten sauropoden Dinosauriern aus der Oberkreide von Südamerika. Basierend auf osteologischen Daten lässt sich eine umfangreiche Invasion von pneumatischen Divertikeln entlang der Wirbelsäule nachweisen, welche sich bis in die distalen Bereiche des Schwanzes erstreckt. Darüber hinaus zeigen sich Hinweise auf Pneumatisierung in beiden Brust- und Beckengürteln. Unsere Studie zeigt, dass diese extreme Form von PSP in Archosauriern nicht auf Flugsaurier und theropode Dinosaurier beschränkt ist.

Schlüsselwörter Sauropoda - Titanosauria - Oberkreide · Luftsacksysteme $\cdot$ Appendikularpneumatisierung

\section{Introduction}

Birds are the only extant group of vertebrates that possesses a pneumatic postcranial skeleton, which results from invasion of bone by extensions (diverticula) from the lung and air-sac system (Britt 1993; Duncker 1971). This feature has also been reported in numerous extinct archosaurs including pterosaurs and non-avian dinosaurs (Benson et al. 2011; Britt 1993; Buttler et al. 2009; Claessens et al. 2009; Janensch 1947; O'Connor 2006; Wedel 2003; Yates et al. 2012). In sauropod dinosaurs, the postcranial skeletal 
pneumaticity (PSP) has been commonly identified in the presacral axial skeleton (including dorsal ribs) and, in some groups, in the sacrum and the proximal and middle caudal vertebrae (Janensch 1947; Schwarz et al. 2007; Wedel et al. 2000; Wedel 2003, 2007, 2009). Pneumatization of the pelvic girdle has been proposed for some Neosauropoda taxa (Carvalho et al. 2003; Hocknull et al. 2009; Wedel 2009; Wilson and Upchurch 2009; Woodward and Lehman 2009; Xu et al. 2006), but based on non-conclusive evidence, and pneumaticity in the pectoral girdle has definitely never been reported in sauropodomorphs.

Several osteological correlates of PSP have been previously proposed for the determination of this feature in fossil groups (Britt 1993). However, recent studies on extant tetrapods have demonstrated that the correlation between many of these purported osteological features (i.e., blind fossae) with PSP is ambiguous (O'Connor 2006; O'Connor and Claessens 2005). The only unambiguous indicators of pneumaticity are large cortical openings (foramina) connected directly with large internal cavities (camerae or camellae) within the bone. Using this anatomical criterion, we study the PSP in a derived clade of titanosaurian sauropods from the Upper Cretaceous of South America [Saltasaurini (Salgado and Bonaparte 2007, Saltasaurinae sensu Salgado et al. 1997, Saltasaurinae sensu Powell 2003)], which actually includes Saltasaurus loricatus from Northwestern Argentina (Bonaparte and Powell 1980; Powell 2003) and Neuquensaurus australis and Rocasaurus muniozi from Northern Patagonia (Powell 2003; Salgado and Azpilicueta 2000).

\section{Institutional abbreviations}

APB: Museo de la Asociación Paleontológica de Bariloche, Río Negro Province, Argentina; MLP-CS, Museo de La Plata, Cinco Saltos Collection, La Plata, Argentina; MLPLy: Museo de La Plata, Lydekker's Collection; PVL: Paleovertebrate collection of Instituto "Miguel Lillo", Tucumán Province, San Miguel de Tucumán, Argentina. MPCA-Pv: Paleovertebrate Collection of Museo Provincial "Carlos Ameghino", Cipolletti, Río Negro Province, Argentina; MCS-Pv, Paleovertebrate Collection of Museo Regional Cinco Saltos, Río Negro Province, Argentina.

\section{Materials and methods}

The examined material of Saltasaurus includes all the specimens referred to by Powell (2003) and identified as PVL 4017 and PVL 4740 (see Powell 2003 for a complete list of the specimens). The material was collected from the Upper Cretaceous (?upper Campanian-Maastrichtian)
Fig. 1 Pneumatic features in the middle and posterior caudal vertebrae of $R$. muniozi $(\mathbf{a}-\mathbf{g})$, S. loricatus $(\mathbf{h}-\mathbf{n})$ and $N$. australis (o-t). a Middle caudal vertebra of Rocasaurus (MPCA-Pv 57). Dashed line indicates the section showed in b. b CT scan of the same specimen. Pneumatic foramina communicated with camellate tissue are clearly observed in the neural arch. In this and the other figures, pneumatic foramina are indicated by arrowheads. c MPCA-Pv 57 in anterior view. d Detail of pneumatic foramina in the base of the neural arch and in the spinoprezygapophyseal fossa (box inset in c). e Middle caudal (MPCA-Pv 58) in lateral view. f Detail of two pneumatic foramina in the lateral surface. $g$ Posterior caudal (MPCA$\mathrm{Pv} 54)$ in ventral view showing a large pneumatic foramina and camellate tissue in the broken surfaces. $\mathbf{h}$ Incomplete middle caudal vertebra (PVL 4017-31). The broken area reveals camellate bone tissue. i Middle caudal (PVL 4740) in anterior view. $\mathbf{j}$ Detail of pneumatic foramina in the base of the neural arch and in the spinoprezygapophyseal fossa. $\mathbf{k}$ The same specimen in lateroposterior view. I Close-up of the pneumatic foramina in the centrum and the neural arch. m Posterior caudal (PVL 4017-38) in lateral view. Dashed line indicates the section showed in $\mathbf{n}$. $\mathbf{n}$ Broken surface showing large pneumatic cavities in the centrum. o Middle caudal vertebra (MCS-Pv 180) in lateral view. p Polished cross section of the same specimen (dashed lines in o) showing pneumatic cavities. Given the poor contrast between bone tissue and sedimentary matrix, the former has been digitally erased. q Middle caudal (MCS-Pv 5-12) in dorsal view. $\mathbf{r}$ Detail of pneumatic foramina in the spinoprezygapophyseal fossa. s Posterior caudal vertebra of MLP-CS 1434 in dorsal view. Note the pneumatic cavities in the base or the neural arch. h Broken surface of the same specimen showing pneumatic cavities filled with matrix. $n c$ Neural canal, $p c$ pneumatic cavities, sprf spinoprezygapophyseal fossa

sediments of the Lecho Formation at the locality of El Brete (south of Salta Province, Argentina) (Bonaparte and Powell 1980; Powell 2003). The specimens of Neuquensaurus were recovered from the localities of Cinco Saltos and Lago Pellegrini (Río Negro Province, Argentina), from sediments of the Anacleto Formation (lower Campanian) (Powell 2003; Salgado et al. 2005; Otero 2010). We examined postcranial elements assigned to Neuquensaurus identified as MCS-Pv 5 (Salgado et al. 2005), MLP-Ly and MLP-CS (see Powell 2003 for a complete list of the materials housed in Museo de La Plata). The assignment of the studied specimens to Neuquensaurus has been previously discussed by several authors (McIntosh 1990; Powell 2003; Wilson and Upchurch 2003; Salgado et al. 2005; Otero 2010). The Rocasaurus material includes the holotype (MPCA-Pv 46) and all the referred material (MPCA-Pv 47-51, MPCA-Pv 56-60 and APB 2887). These specimens were collected from sediments of the Allen Formation (middle Campanian-lower Maastrichtian) of the locality of Salitral Moreno (Río Negro Province, Argentina) (Salgado and Azpilicueta 2000).

The internal structure of the examined bones was studied by observation of: fortuitous breaks in specimens (all the three taxa); mechanical sections (Saltasaurus) and nondestructive computed tomography (CT) (vertebrae of Neuquensaurs and Rocasaurus). Obtaining images by CT scanning was not possible for Saltasaurus, because of the 

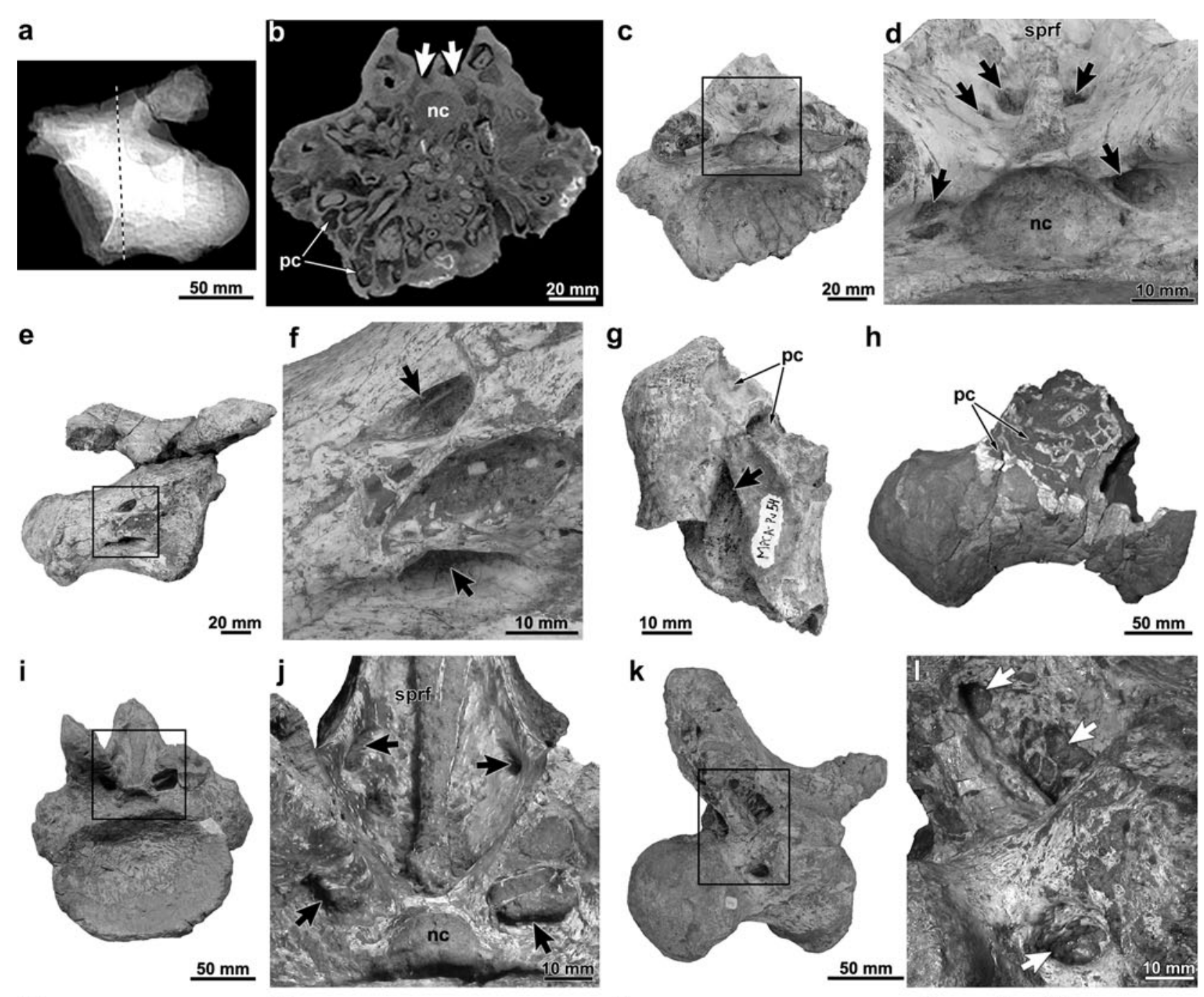

h
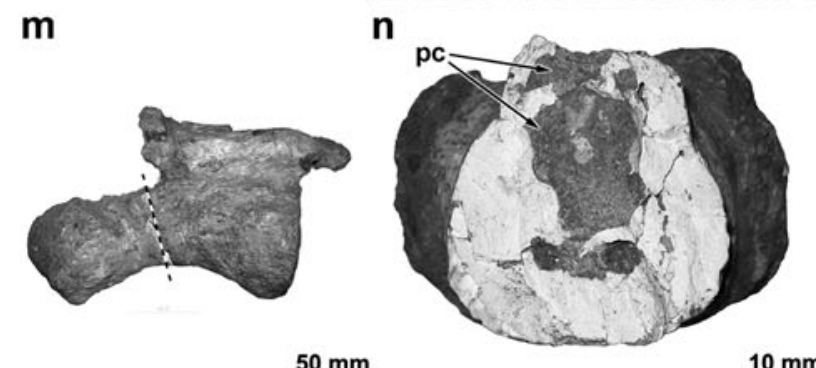

o
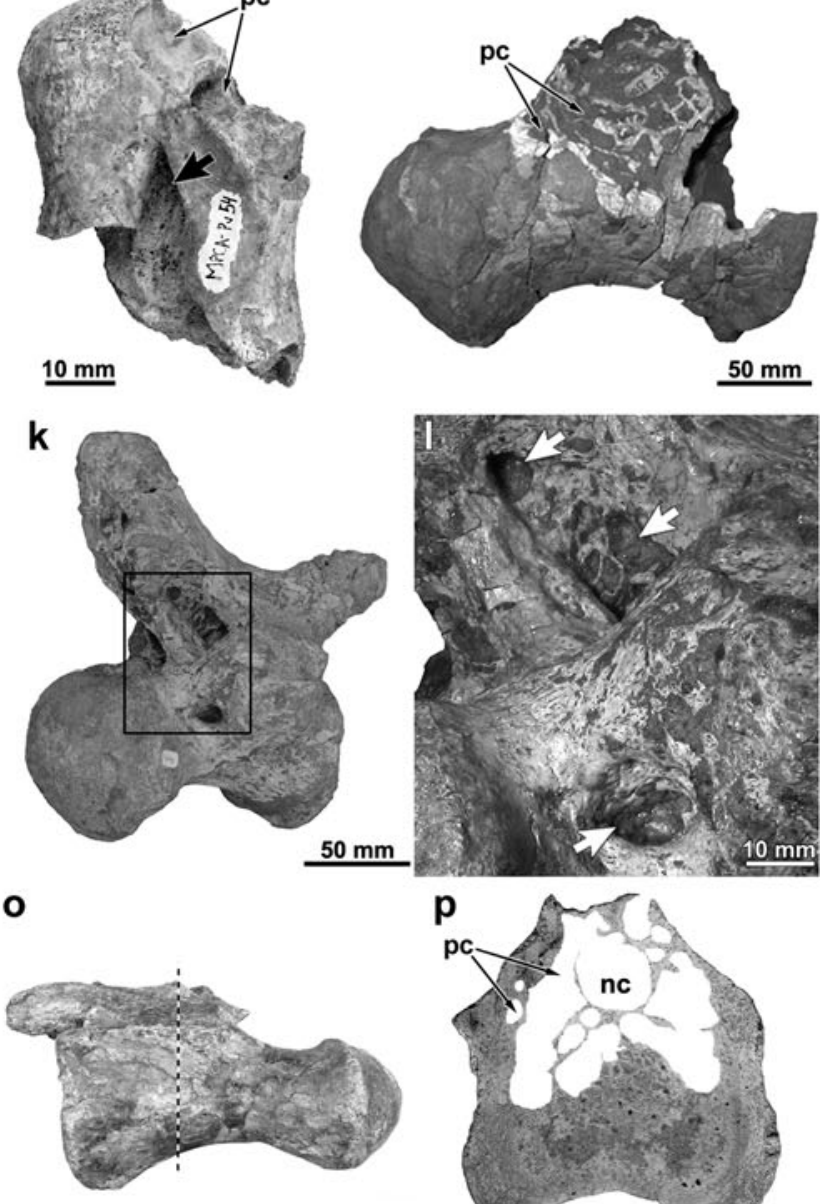

$50 \mathrm{~mm}$
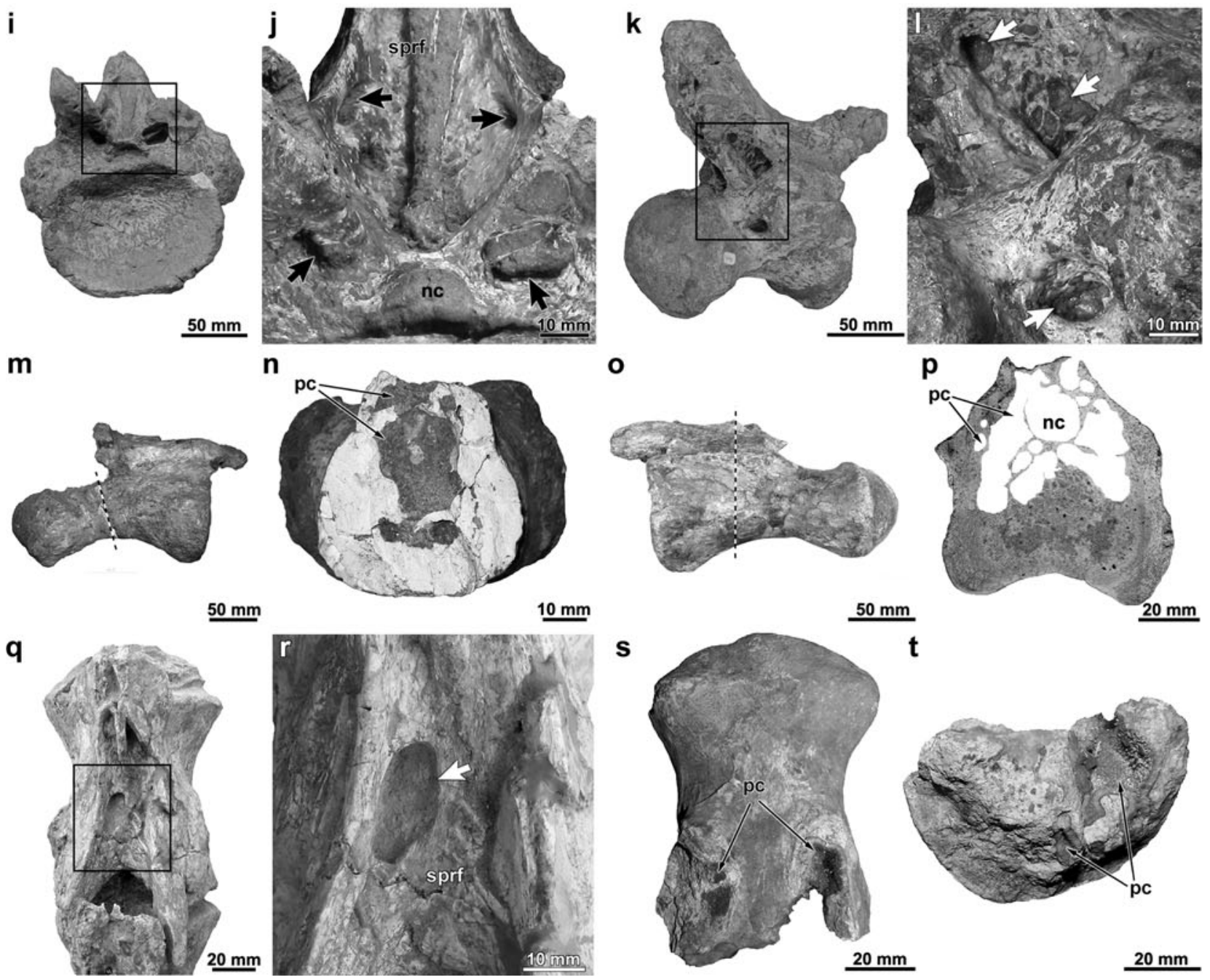

$\mathbf{t}$

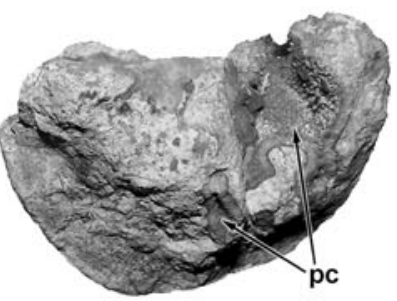

$20 \mathrm{~mm}$ 
prevalent heavy elements in its sedimentary matrix. The CT scanning of the different bones was conducted on a Pro Speed helicoidal scanner (99783 Pro Gp serie) housed at Policlínico Neuquén (Neuquén Province, Argentina). Vertebral laminae and fossae terminology follows Wilson (2000) and Wilson et al. (2011). Pneumatic structure nomenclature follows Britt (1993) and Wedel et al. (2000).

\section{Results}

Saltasaurini titanosaurs show evidence of PSP in both the axial and appendicular skeleton. Given that PSP in the precaudal axial skeleton of sauropod dinosaurs has been largely described previously (Britt 1993; Janensch 1947; Schwarz et al. 2007; Wedel 2003, 2007, 2009), we focused our description on the caudal vertebrae and the appendicular skeleton of Saltasaurini titanosaurs. The centra and neural arches of anterior and middle caudal vertebra of Saltasaurus and Rocasaurus have a camellate ("honeycomb"-like) internal structure consisting of a large number of small ( 5-20-mm-diameter $)$ internal chambers (camellae) that are observed on broken and abraded surfaces and in CT imagery (Fig. 1). Posterior caudal neural arches also possess an internal camellate architecture, but the posterior centra are semicamellate, with large $(\sim 20 \mathrm{~mm}$ diameter) camerae that divide into a numerous smaller camellae (Fig. 1a-n). Large ( $\sim 5-45 \mathrm{~mm}$ diameter) foramina are observed on the lateral and ventral surfaces of the centrum and in different positions of the neural arch (i.e., the spinoprezygapophyseal fossa, base of the prezygapophysis) (Fig. 1b-d, i-l). As observed in Saltasaurus and Rocasaurus, the caudal neural arches of Neuquensaurus are internally composed of camellate tissue. However, the internal architecture of the caudal centra differs from the typical "honeycomb" morphology described for the other taxa. Instead, the internal cavities have a quite variable morphology and size (larger cavities reach $\sim 45 \mathrm{~mm}$ diameter) (Fig. 1o, p). Also, while the pneumatized caudal vertebrae of Saltasaurus and Rocasaurus are perforated by foramina in both centra and neural arches, caudal centra of Neuquensaurus lack these openings. The cortical foramina observed in Neuquensaurus are commonly located in the spinoprezygapophyseal fossa and in the posterior end of the neural spine (between or above the postzygapophysis) (Fig. 1q-t). Another important difference between $\mathrm{Neu}$ quensaurus and the other Saltasaurini titanosaurs lies in the intraspecific variation with regard to the extension of the pneumaticity in the caudal series. While in all the examined specimens of Saltasaurus and Rocasaurus the internal cavities are present even in the posterior portion of the tail, some specimens of Neuquensaurus (e.g., MLP-CS 1320) lack pneumatic structures in this portion of the skeleton.
The pectoral girdle is at least pneumatized in Saltasaurus and Neuquensaurus (it is not preserved in Rocasaurus) (Fig. 2). A broken scapula (PVL 4017-153) of Saltasaurus exhibits a camellate internal structure, with large (more than $20 \mathrm{~mm}$ diameter) and elongated cavities (Fig. 2a, b). No pneumatic foramina were recorded in this element. The two preserved coracoids of Saltasaurus (PVL 4017-100 and PVL 4017-101) also possess a camellate architecture, with well-developed internal cavities ( $\sim 10-20 \mathrm{~mm}$ diameter). The cortical pneumatic foramina of the coracoids are small $(5-10 \mathrm{~mm})$, and they are located on the medial surface, near the coracoid foramen (Fig. 2c-e). Pneumaticity in the scapular girdle of Neuquensaurus is well observed in an incomplete scapulocoracoid (MLP-CS 1298). This element reveals internal cavities in both fused bones. A prominent pneumatic foramen ( $9 \mathrm{~mm}$ diameter) is observed on the medial surface of the scapula, at the level of the glenoid fossa, toward the dorsal margin (Fig. 2f-h).

Pneumaticity of the pelvic girdle is restricted to the ilium in Saltasaurini titanosaurs (Fig. 3). This element exhibits camellate tissue in the three examined taxa. Although the exact distribution of the camellate tissue in the ilia cannot be determined, the broken surfaces of the examined elements indicate that large camellae (more than $10 \mathrm{~mm}$ diameter) are mainly distributed in the anterior and middle portion of the iliac blade, but they do not invade the pubic peduncle (Fig. 3a-i). Pneumatic foramina are observed in a specimen of Neuquensaurus (MLP-CS 1057) and in the holotype of Rocasaurus (MPCA-Pv 46-12). In Rocasaurus, a prominent foramen of $31 \mathrm{~mm}$ is located on the dorsal margin of the acetabulum (Fig. 3e, f). In the Neuquensaurus specimen, a small (9-mm-diameter) cortical foramen is observed on the medial surface of the ilium, at the level of the pubis peduncle, between two successive sacral rib facets (possibly the third and the fourth) (Fig. 3h, i).

\section{Discussion}

\section{Appendicular pneumaticity}

Among sauropod dinosaurs, internal cavities (camerae and camellae) have been previously reported in the pelvic girdle (ilia) of several taxa, including: Euhelopus zdanskyi (Wilson and Upchurch 2009; Wiman 1929), Lirainosaurus astibiae (Sanz et al. 1999), Amazonsaurus maranhensis (Carvalho et al. 2003), Sonidosaurus saihangaobiensis (Xu et al. 2006), Diamantinasaurus matildae (Hocknull et al. 2009) and Alamosaurus sanjuanensis (Woodward and Lehman 2009). These cavities have been interpreted by some authors as pneumatic (Carvalho et al. 2003; Hocknull et al. 2009; Wedel 2009; Wilson and Upchurch 2009; Woodward and Lehman 2009; Xu et al. 2006). However, at 
a

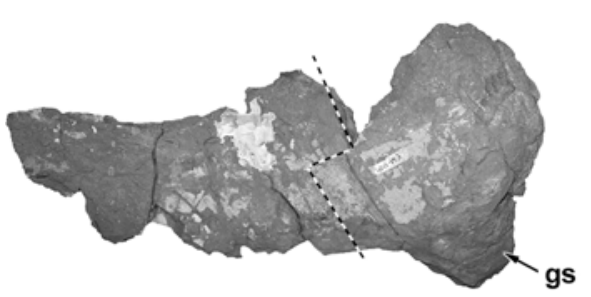

$100 \mathrm{~mm}$

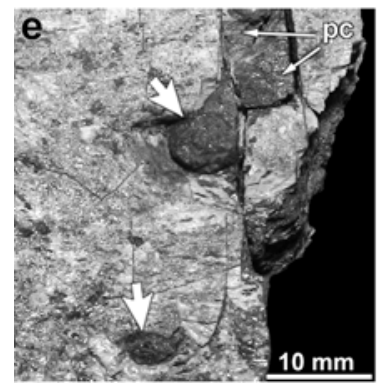

f

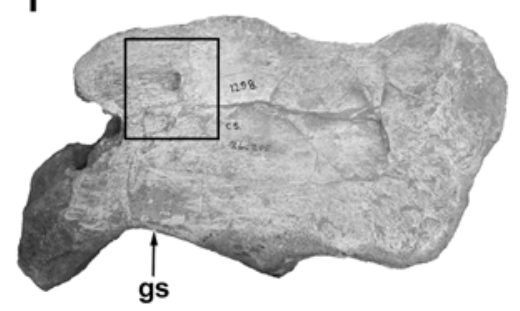

$\underline{50 \mathrm{~mm}}$
C

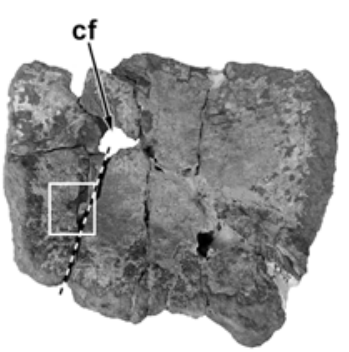

d

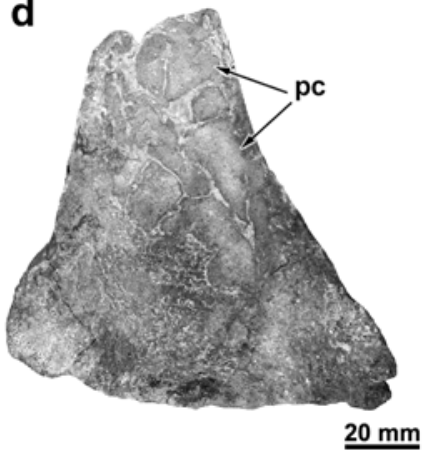

$50 \mathrm{~mm}$

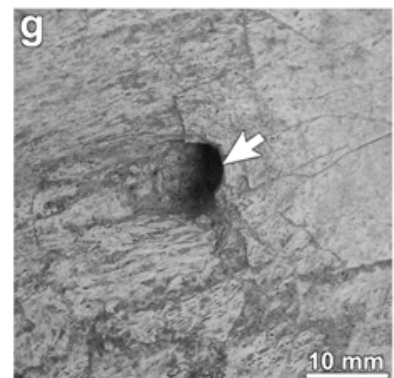

h

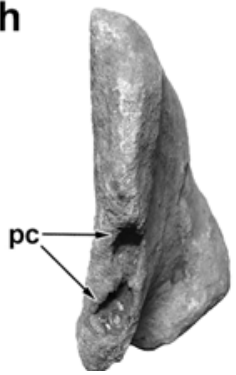

$\underline{20 \mathrm{~mm}}$
Fig. 2 Pneumatic features in the pectoral girdle of $S$. loricatus (a-e) and $N$. australis (f-h). a Incomplete left scapula (PVL 4017-153) in medial view. b Broken surface of the same specimen (dashed lines in a) showing the camellate internal bone. c, Left coracoid (PVL 4017-101) in medial view. d Broken surface of the same specimen revealing the distribution of the camellate tissue. e Close-up of the pneumatic foramina in PVL 4017-101 (box inset in c). Note the presence of internal camellae communicated with the larger foramina. f Fragment of scapulocoracoid (MLP-CS 1298) in medial view. g Detail of the pneumatic foramina in the medial surface. h MLP-CS 1298 in anterior view. Note the presence of pneumatic cavities in the broken surface. $c f$ Coracoid foramen, $g s$ glenoid surface, $p c$ pneumatic cavities present, there are no reports in sauropodomorphs of cortical foramina communicating with the internal cavities of the ilia. As has been previously stated, the only unambiguous indicators of pneumaticity are large foramina connected directly with large internal cavities (camerae or camellae) within the bone (O'Connor 2006; O'Connor and Claessens 2005). Our finding gives the first report of a cortical foramen communicated with internal cavities in the ilium and supports the previous hypothesis of the invasion of pneumatic diverticula in the pelvic girdle in some Neosauropoda taxa. We note that in several badly damaged Saltasaurini bones (e.g., Saltasaurus scapula PVL 4017-153, Neuquensaurus ilium MLP-CS 1259, Rocasaurus ilium MPCA-Pv 46-13), the camellate tissue is present but the pneumatic foramina could not be found. We infer that the pneumatic foramina were actually present but obscured by the poor preservation of the bones. The same explanation could be applied to those non-Saltasaurini sauropods for which camellate tissue has been reported in the ilium. Hence, as has been previously proposed by Wedel (2003, 2005, 2009), the invasion of pneumatic diverticulae in the ilium appears to be an extended character within derived neosauropod dinosaurs.

With regard to the pneumatic invasion in the pectoral girdle of Saltasaurus and Neuquensaurus, there are no previous reports of internal cavities in this portion of the skeleton of sauropodomorph dinosaurs. Thus, Saltasaurini titanosaurs are the only known group of sauropodomorph dinosaurs with this character. Given that the scapular girdle is not preserved in Rocasaurus, it is not possible to determine if pneumatic features in this element are present by direct observation. However, since Neuquensaurus is the sister group of the clade formed by Rocasaurus + Saltasaurus (Calvo et al. 2007a, b; González Riga et al. 2009), we hypothesize that camellate tissue and cortical foramina were actually present in the scapula and coracoides of Rocasaurus.

\section{Caudal pneumaticity}

Previous studies have documented the existence of pneumatic features in the anterior and even in the middle caudal vertebrae of some Neosauropoda taxa (Janensch 1947; Salgado et al. 2006; Wedel 2009). However, pneumaticity in the distal portion of the tail as described here for Saltasaurini titanosaurs has not been previously reported in sauropodomorph dinosaurs. Our data reveal an unexpected caudal extension of the pneumatic diverticula from the respiratory system, only comparable to some lineages of non-avian theropods (Benson et al. 2011). 
a

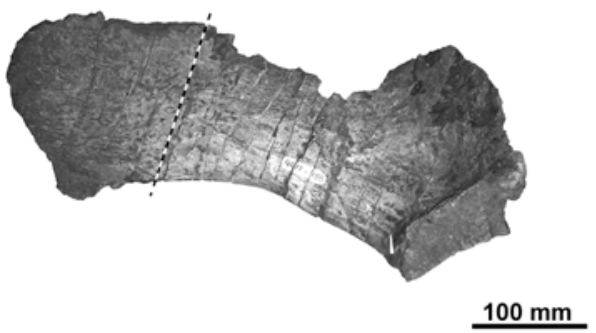

e
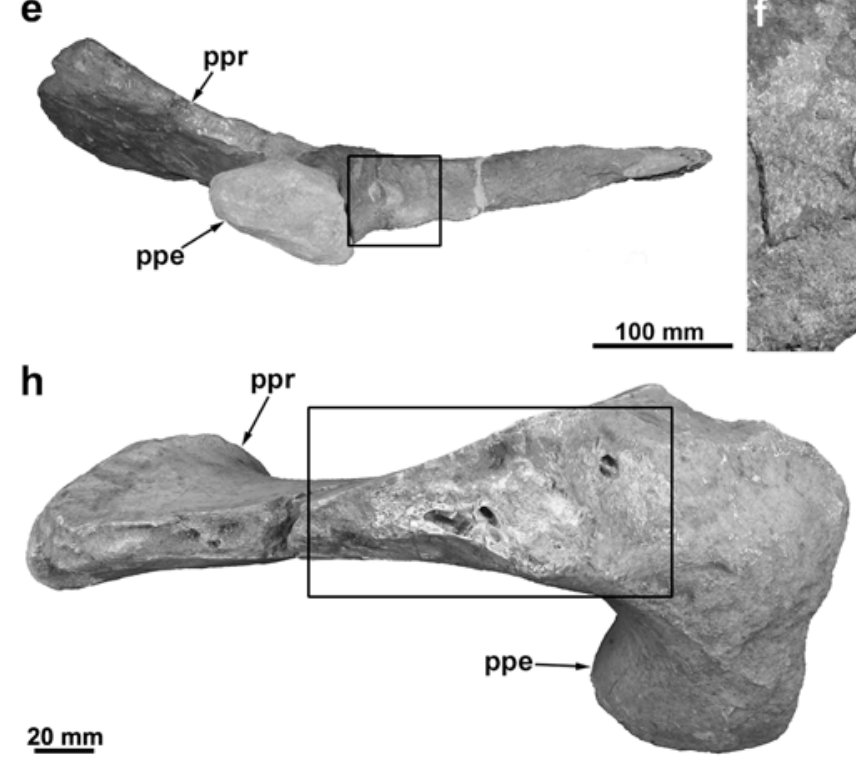

Fig. 3 Pneumatic features in the pelvic girdle of $S$. loricatus $(\mathbf{a}-\mathbf{b})$, R. muniozi $(\mathbf{c}-\mathbf{f})$ and $N$. australis $(\mathbf{g}-\mathbf{i})$. a Preacetabular process of left ilium (PVL 4017-155) in latero-posterior view. b Broken surface of the same specimen (dashed lines in a) showing the camellate internal bone in the dorsal region. c Fragment of right ilium (MPCA-Pv 46-13) in lateral view. d Broken surface of the same specimen (box inset in c) showing the internal camellate tissue. e Left ilium (MPCA-

\section{Body size and postcranial pneumaticity}

Since the development of PSP is thought to have been very important in the achievement of giant size in sauropodomorph dinosaurs (Sander et al. 2011), the extreme pneumaticity in Saltasaurini is rather unexpected. Saltasaurini titanosaurs represent one of the few cases of phylogenetic decrease in body size among dinosaurs (Wilson 2005). This group has been considered as the "smallest of the giants," with body lengths that probably did not exceed $7 \mathrm{~m}$. Our data reveal that one of the smallest sauropod clades actually has the most developed PSP. In this sense, although body size seems to be important in the development of PSP in sauropod dinosaurs (Britt 1993; Wedel 2003), this is not the only factor governing the evolution of pneumaticity. A detailed analysis on a larger data set, including species-level information, is necessary to elucidate which are the main
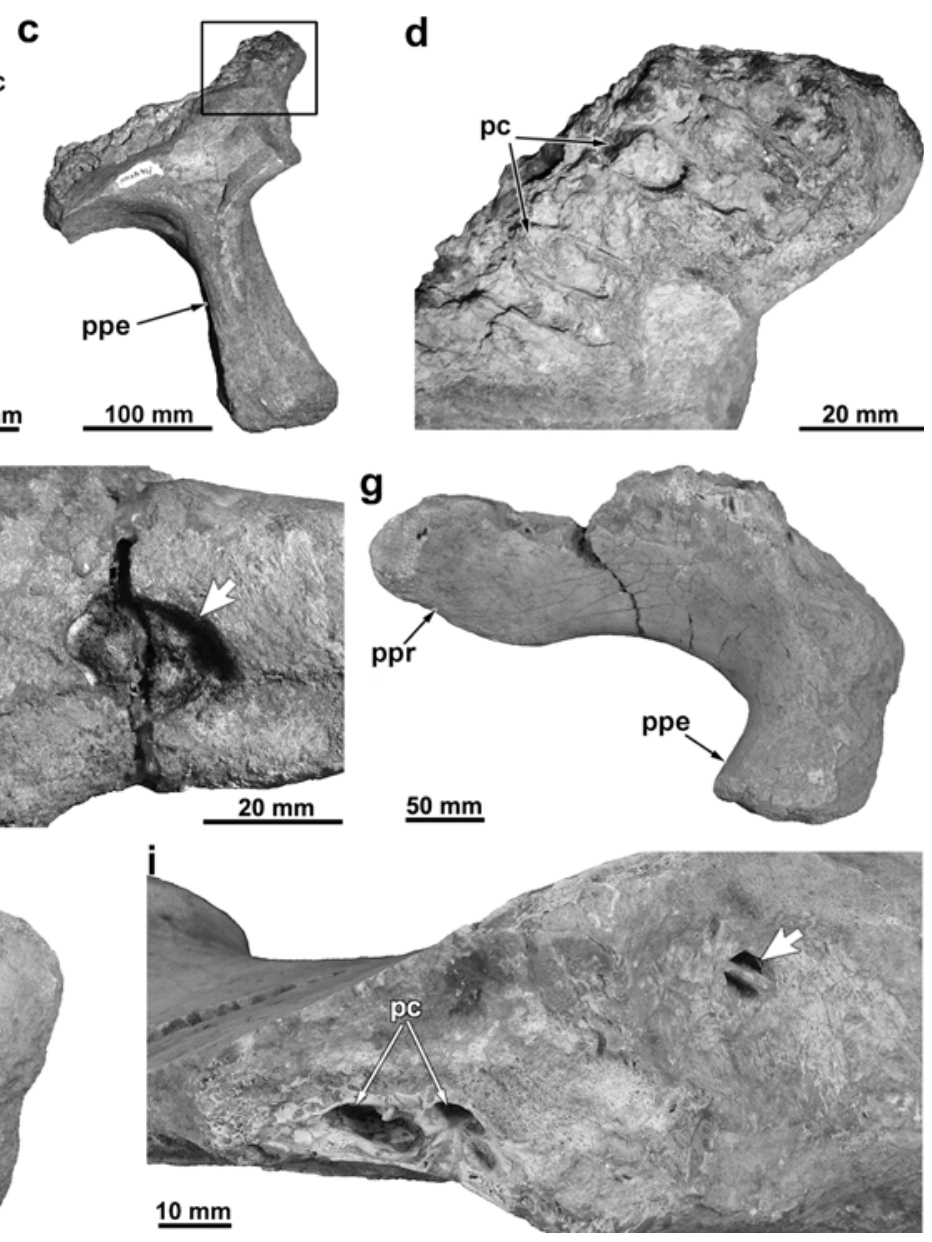

Pv 46-12) in ventral view. f Close-up of the same specimen showing a prominent foramen in the dorsal region of the acetabulum. $\mathrm{g}$ Incomplete right ilium (MLP-CS 1057) in postero-medial view. h The same specimen in dorsal view. i Detailed view of the same specimen showing a well-developed pneumatic foramen on the medial surface and camellate tissue in the broken area. $p c$ Pneumatic cavities, $p p r$ preacetabular process, ppe pubic peduncle

factors involved in the development of PSP in sauropod dinosaurs.

\section{Structure of respiratory system}

The identification of postcranial pneumaticity in fossil groups indicates the presence of an avian-like, heterogeneously partitioned pulmonary system, composed of both exchange (lung) and non-exchange (air sac) regions (O'Connor 2006; O'Connor and Claessens 2005). In extant birds, the air sac system includes the cervical, clavicular (= interclavicular), anterior thoracic, posterior thoracic and abdominal air sacs (Duncker 1971; Perry et al. 2011). Recent work has demonstrated that strict correlations exist between specific air sacs and the axial elements that they pneumatize in living birds (O'Connor 2006; O'Connor and Claessens 2005; contra Sereno et al. 2008). 


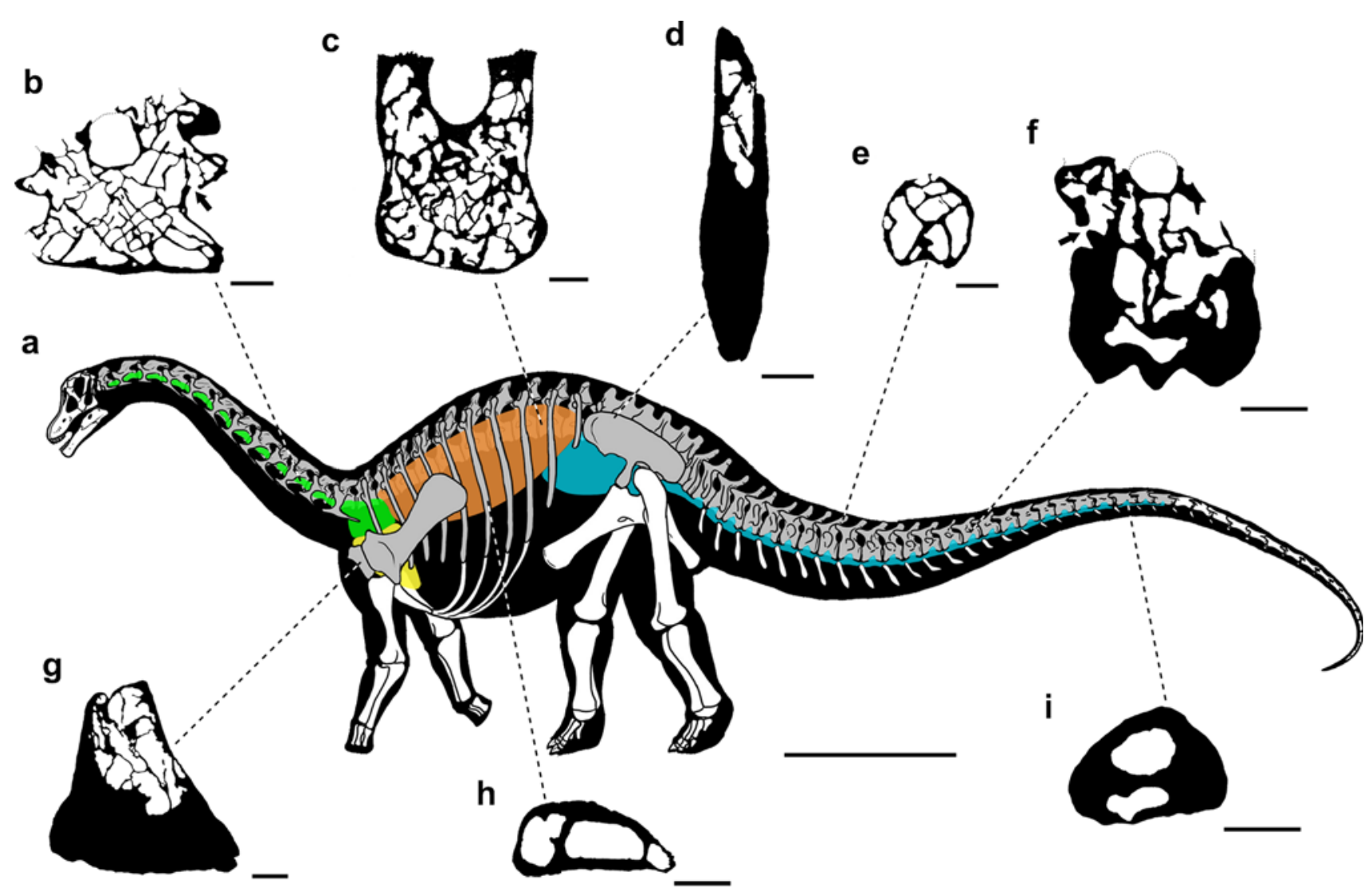

Fig. 4 Reconstruction of pulmonary air sac in S. loricatus. a Skeletal reconstruction in lateral left view showing pneumatized postcranial bones (gray). The reconstruction is based on different specimens, and unknown skeletal parts (i.e. portions of the skull and the distal-most elements of the hind-limb) are based on closely related titanosaurs. Components of the pulmonary air sac system are based on sitespecific pneumaticity of the postcranial skeleton and include: the cervical system (green), lung (orange), clavicular system (yellow) and abdominal system (blue). b-i Cross section of different elements

When the postcranial skeleton is pneumatized, the cervical vertebrae/ribs and the anterior dorsal vertebrae are pneumatized by diverticula of the cervical air sacs; in turn, diverticula of the abdominal air sacs pneumatize pelvic girdle and hind limb elements and the posterior dorsal, sacral and caudal vertebrae; finally, diverticula from the clavicular air sac pneumatize pectoral girdle and forelimb elements, whereas dorsal vertebrae and ribs are pneumatized directly by the lung. Anterior thoracic air sac diverticula often pneumatize the sternum and sternal ribs, and posterior thoracic air sacs never pneumatize the skeleton. Previous studies used this conservative pattern of PSP in living birds to infer the presence of specific air sacs in extinct archosaurs, including pterosaur, sauropodomorph and non-avian theropods (Claessens et al. 2009; O'Connor 2006; O'Connor and Claessens 2005; Wedel 2009; Yates et al. 2012). Following this reasoning, the pneumatic features observed in the postcranial skeleton of Saltasaurini implies the presence of cervical, abdominal and clavicular air sacs in this clade (Fig. 4). Although previous showing internal cavities. b Incomplete posterior cervical vertebra (PVL 4017-214). c Middle dorsal vertebral centrum (PVL 4017-47). d Preacetabular process of a left ilium (PVL 4017-155). e Neural spine of middle caudal vertebra (PVL 4017-192). f Middle caudal centrum (PVL 4017-37). g Left coracoid (4017-101). h Thoracic rib (PVL 4017-143). i Posterior caudal centrum (PVL 4017-14). Arrowheads indicate pneumatic foramina included in the sections. Scale bar equals $100 \mathrm{~cm}(\mathbf{a})$ and $2 \mathrm{~cm}(\mathbf{b}-\mathbf{i})$

studies of PSP have proposed that cervical and abdominal air sacs were actually present in sauropodomorph dinosaurs (Wedel et al. 2000; Wedel 2007, 2009; Yates et al. 2012), anatomical evidence for clavicular air sacs has never been reported in this group.

Although the presence of PSP is indicative of air sacs and diverticula, the lack of pneumaticity does not indicate the absence of such pulmonary specializations (O'Connor 2006; Wedel 2003, 2007, 2009). Hence, it is very plausible that the clavicular air sac was actually present in a more inclusive clade of sauropodomorph dinosaurs, but its osteological correlates were only present in Saltasaurini titanosaurs. A similar hypothesis has been proposed for the cervical and abdominal air sacs in basal sauropodomorph dinosaurs, for which unambiguous correlates of PSP are absent or poorly documented (Butler et al. 2012; Wedel 2007, 2009; Yates et al. 2012).

Since PSP has been recorded in different lineages of ornithodiran archosaurs (pterosaurs, sauropodomorph and 
non-avian theropod dinosaurs), several authors have proposed that the presence of a heterogeneously partitioned pulmonary system is primitive for ornithodiran archosaurs (Benson et al. 2011; Britt 1993; Butler et al. 2012; Wedel 2003, 2007; Yates et al. 2012). The extreme PSP reported here for Saltasaurini titanosaurs, with evidence of cervical, abdominal and clavicular air sacs, reinforces this idea. The independent acquisition of appendicular pneumaticity in pterosaurs (Claessens et al. 2009) and dinosaurs (theropods and derived sauropodomorphs) (Benson et al. 2011; Wedel 2009) emphasizes the tendency for ornithodirans to extensively pneumatize the postcranial skeleton (Benson et al. 2011; Butler et al. 2012).

\section{Conclusions}

Osteological features of the axial and appendicular skeleton in Saltasaurini titanosaurs reveal extreme pneumaticity that is unparalleled in other sauropodomorph dinosaurs, with invasion of pneumatic diverticula in the pectoral girdle and the distal portion of the tail. Our result indicates that, besides pterosaurs and theropod dinosaurs, extensive pneumaticity was also reached independently in Sauropodomorpha. Our data also strengthen the hypothesis for the presence of posterior abdominal air sacs in sauropodomorph dinosaurs and provide the first evidence for a clavicular air sac in this lineage. Finally, the record of extreme PSP in Saltasaurini titanosaurs contributes to the growing evidence of widespread, repeated evolution of appendicular and posterior axial skeletal pneumaticity in ornithodiran archosaurs, which in turn indicates that a heterogeneously partitioned pulmonary system is primitive for this group.

Acknowledgments We thank Marcelo Reguero, Lucas Pomi, Carlos Muñoz, Norma Brugni and all the staff of Comision Amigos del Museo of Cinco Saltos for access to the specimens under their care, Maia Quintili, Silvia Fasano, Juan José Perazzolo and the authorities of the Policlinico Neuquén for CT scans, Brooks Britt for access to his unpublished $\mathrm{PhD}$ thesis, Rodrigo Pellegrini for reading the text and useful comments, Torsten Scheyer for translating the abstract into German and Jorge González for the skeletal reconstruction of Saltasaurus in Fig. 2. The quality of is work has been substantially improved by the useful comments and critical reviews of Roger Benson, Paul Upchurch and Richard Butler. This work was supported by Conicet (PIP 6455 to L.S) and Agencia de Promoción Científica y Técnica (PICT 357 to L.S.).

\section{References}

Benson, R.B.J., R.J. Butler, M.T. Carrano, and P.M. O'Connor. 2011. Air-filled postcranial bones in theropod dinosaurs: Physiological implications and the 'reptile'-bird transition. Biological Reviews of the Cambridge Philosophical Society. doi:10.1111/j.1469185X.2011.00190.x.
Bonaparte, J.F. and Powell. J.E. 1980. A continental assemblage of tetrapods from the Upper Cretaceous beds of El Brete, northwestern Argentina (Sauropoda-Coelurosauria-Carnosauria-Aves). Mémories de la Sociejété Géologique de France 139:19-28.

Britt, B.B. 1993. Pneumatic postcranial bones in dinosaurs and other archosaurs. Dissertation, University of Calgary.

Buttler, R.J., P.M. Barrettt, and D.J. Gower. 2009. Postcranial skeletal pneumaticity and air-sacs in the earliest pterosaurs. Biology Letters 5: 557-560. doi:10.1098/rsbl.2009.0139.

Butler, R.J., P.M. Barrett, and D.J. Gower. 2012. Reassessment of the evidence for postcranial skeletal pneumaticity in Triassic archosaurs, and the early evolution of the avian respiratory system. PLoS One 7(3): e34094. doi:10.1371/journal.pone. 0034094.

Calvo, J.O., B.J. González Riga, and J.D. Porfiri. 2007a. A new titanosaur sauropod from the Late Cretaceous of Neuquén, Patagonia, Argentina. Arquivos do Museu Nacional 65: 485-504.

Calvo, J.O., J.D. Porfiri, B.J. González Riga, and A.W.A. Kellner. 2007b. A new Cretaceous terrestrial ecosystem from Gondwana with the description of a new sauropod dinosaur. Anais da Academia Brasileira de Ciencias 79: 529-541.

Carvalho, I.S., L. dos Santos Avilla, and L. Salgado. 2003. Amazonsaurus maranhensis gen. et sp. nov. (Sauropoda, Diplodocoidea) from the Lower Cretaceous (Aptian-Albian) of Brazil. Cretaceous Research 24: 697-713.

Claessens, L.P.A., P.M. O'Connor, and D.M. Unwin. 2009. Respiratory evolution facilitated the origin of pterosaur flight and aerial gigantism. PLoS One 4: e4497. doi:10.1371/journal.pone. 0004497.

Duncker, H.-R. 1971. The lung air-sac system of birds. Advances in Anatomy, Embroylogical and Cell Biology 45: 1-171.

Gonzáles Riga, B.J., E. Previtera, and C.A. Pirrone. 2009. Malarguesaurus florenciae gen. et sp. nov., a new titanosauriform (Dinosauria, Sauropoda) from the Upper Cretaceous of Mendoza, Argentina. Cretaceous Research 30: 135-148.

Hocknull, S.A., M.A. White, T.R. Tischler, A.G. Cook, N.D. Calleja, T. Sloan, and E.A. Elliott. 2009. New Mid-Cretaceous (Late Albian) Dinosaurs from Winton, Queensland, Australia. PLos One 4(7): e6190. doi:10.1371/journal.pone.0006190.

Janensch, W. 1947. Pneumatizitat bei Wirbeln von sauropoden und anderen saurischien. Palaeontographica 3: 1-25.

McIntosh, J.S. 1990. Sauropoda. In The Dinosauria 1st edn, eds. D.B. Weishampel, P. Dodson \& H. Osmólska, 345-401. Berkeley: University of California Press.

O'Connor, P.M. 2006. Postcranial pneumaticity: An evaluation of soft-tissue influences on the postcranial skeleton and the reconstruction of pulmonary anatomy in archosaurs. Journal of Morphology 267: 1199-1226. doi:10.1002/jmor.10470.

O'Connor, P.M., and L.P.A. Claessens. 2005. Basic avian pulmonary design and flow-through ventilation in nonavian theropod dinosaurs. Nature 436: 253-256. doi:10.1038/nature03716.

Otero, A. 2010. The appendicular skeleton of Neuquensaurus, a Late Cretaceous saltasaurine sauropod from Patagonia, Argentina. Acta Palaeontologica Polonica 55: 399-426.

Perry, S.F., T. Breuer, and N. Pajor. 2011. Structure and function of the sauropod respiratory system. In Biology of the sauropod dinosaurs: Understanding the life of giants, ed. N. Klein, K. Remes, C.T. Gee, and P.M. Sander, 83-93. Bloomington and Indianapolis: Indiana University Press.

Powell, J.E. 2003. Revision of South American Titanosaurid dinosaurs: Palaeobiological, palaeobiogeographical and phylogenetic aspects. Records of the Queen Victoria Museum 111: 1-173.

Salgado, L., S. Apesteguía, and S.E. Heredia. 2005. A new specimen of Neuquensaurus australis, a Late Cretaceous saltasaurine titanosaur from North Patagonia. Journal of Vertebrate Paleontology 25: 623-634. 
Salgado, L., and C. Azpilicueta. 2000. Un nuevo saltasaurino (Sauropoda, Titanosauridae) de la Provincia de Río Negro (Formación Allen, Cretácico Superior), Patagonia, Argentina. Ameghiniana 37: 259-264.

Salgado, L., R.A. García, and J.D. Daza. 2006. Consideraciones sobre las láminas neurales de los dinosaurios saurópodos y su significado morfofuncional. Revista del Museo Argentino de Ciencias Naturales 8: 69-79.

Salgado, L., and J.F. Bonaparte. 2007. Sauropodomorpha. In Patagonian Mesozoic reptiles, ed. Z. Gasparini, L. Salgado, and R.A. Coria, 188-228. Indiana: Indiana University Press.

Salgado, L., R.A. Coria, and J.O. Calvo. 1997. Evolution of titanosaurid sauropods. I: Phylogenetic analysis based en the postcranial evidence. Ameghiniana 34: 3-32.

Sander, P.M., A. Christian, M. Clauss, R. Fechner, C.T. Gee, E.M. Griebeler, H.C. Gunga, J. Hummel, H. Mallison, S.F. Perry, H. Preuschoft, O.W.M. Rauhut, K. Remes, T. Tütken, O. Wings, and U. Witzel. 2011. Biology of the sauropod dinosaurs: The evolution of gigantism. Biological Reviews of the Cambridge Philosophical Society 86: 117-155. doi:10.1111/j.1469-185X. 2010.00137.x.

Sanz, J.L., J.E. Powell, J. Le Loeuff, R. Martínez, and X. Pereda Suberbiola. 1999. Sauropod remains from the Upper Cretaceous of Laño (northcentral Spain). Titanosaur phylogenetic relationships. Estudios del Museo de Ciencias Naturales de Lava 14: 235-255.

Sereno, P.C., R.N. Martínez, J.A. Wilson, D.J. Varrichio, O.A. Alcober, and H.C.E. Larsson. 2008. Evidence for avian intrathoracic air sacs in a new predatory dinosaur from Argentina. PLoS One 3: e3303. doi:10.1371/journal.pone.0003303.

Schwarz, D., E.D. Frey, and C. Meyer. 2007. Pneumaticity and softtissue reconstructions in the neck of diplodocid and dicraeosaurid sauropods. Acta Palaeontologica Polonica 52: 167-1188.

Wedel, M.J. 2007. What pneumaticity tells us about 'prosauropods', and vice versa. Special Papers in Palaeontology 77: 207-222.

Wedel, M.J. 2009. Evidence for bird-like air-sacs in saurischian dinosaurs. Journal of Experimental Zoology A 311: 611-628. doi:10.1002/jez.513.
Wedel, M.J. 2003. Vertebral pneumaticity, air sacs, and the physiology of sauropod dinosaurs. Paleobiology 29: 243-255. doi: 10.1666/0094-8373(2003)029<0243:VPASAT>2.0.CO;2.

Wedel, M.J., R.L. Cifelli, and R.K. Sanders. 2000. Osteology, paleobiology, and relationships of the sauropod dinosaur Sauroposeidon. Acta Palaeontologica Polonica 45: 343-388.

Wilson, J.A. 2000. A nomenclature for vertebral laminae in sauropods and other saurischian dinosaurs. Journal of Vertebrate Paleontology 19: 639-656.

Wilson, J.A. 2005. Overview of sauropod phylogeny and evolution. In The sauropods: Evolution and paleobiology, ed. K. Curry Rogers, and J.A. Wilson, 15-49. Berkeley: University of California Press.

Wilson, J.A., and P. Upchurch. 2003. A revision of Titanosaurus Lydekker (Dinosauria-Sauropoda), the first dinosaur genus with a "Gondwanan" distribution. Journal of Systematic Palaeontology 1: 125-160.

Wilson, J.A., and P. Upchurch. 2009. Redescription and reassessment of the phylogenetic affinities of Euhelopus zdanskyi (Dinosauria: Sauropoda) from the Early Cretaceous of China. Journal of Systematic Palaeontology 7: 199-239.

Wilson, J.A., M.D. D'Emic, T. Ikejiri, E.M. Moacdieh, and J.A. Whitlock. 2011. A nomenclature for vertebral fossae in sauropods and other saurischian dinosaurs. PLoS One 6(2): e17114. doi:10.1371/journal.pone.0017114.

Wiman, C. 1929. Die Kreide-Dinosaurier aus Shantung. Palaeontologia Sinica (series C) 6: 1-67.

Woodward, H.N., and T. Lehman. 2009. Bone histology and microanatomy of Alamosaurus sanjuanensis (Sauropoda, Titanosauria) from the Maastrichtian of the Big Bend National Park, Texas. Journal of Vertebrate Paleontology 29: 807-821.

Yates, A.M., M.J. Wedel, and M.F. Bonnan. 2012. The early evolution of postcranial skeletal pneumaticity in sauropodomorph dinosaurs. Acta Palaeontologica Polonica 57: $85-100$.

Xu, X., X. Zhang, Q. Tan, J. Wang, X. Zhao, and L. Tan. 2006. A new titanosaurian sauropod from Late Cretaceous of Nei Mongol. Acta Geologica Sinica 80: 20-26. 